\title{
BIZTOSÍTÁSI MEGÁLLAPODÁS, MINT AZ ÖNKÉNTES BIZTOSÍTÁSI KÖTELEZETTSÉGEK KELETKEZÉSÉNEK ALAPJA UKRAJNÁBAN
}

\author{
Insurance Agreement as a Basis for Obligatory Liability \\ Insurance in Ukraine
}

\section{Buleca Szibilla ${ }^{1}$ - Csepisz Oleszja ${ }^{2}$ - Revucka Irina ${ }^{3}$}

\begin{abstract}
Absztrakt: A tudományos cikk az önkéntes biztosítási kötelezettségek alapjául szolgáló biztosítási szerződés tanulmányozásáról szól Ukrajnában. A cikk elemzi annak sajátosságait, alapvető feltételeit, a felek jogait és kötelezettségeit, a szerződés formáját és a szerződés megkötésére vonatkozó eljárást, a szerződés megszűnésének indoklását és jogkövetkezményeit, valamint a biztosítási szerződések megkötésének jelenlegi állapotát és dinamikáját Ukrajnában.
\end{abstract}

Kulcsszavak: biztosítás, biztosító, biztosítási szerződés, önkéntes és kötelező biztosítás

Abstract: The scientific article is devoted to the research of the insurance contract as a basis for the emergence of voluntary insurance obligations in Ukraine. Its features, essential conditions, rights and obligations of the parties, the form of the contract and the procedure for its conclusion, the grounds and legal consequences of termination of the contract, as well as the current state and dynamics of concluding insurance contracts in Ukraine are analyzed.

1 Buleca Szibilla, DJSc, Dr. Habil, az Ungvári Nemzeti Egyetem Állami Felsőoktatási Intézmény jogi karán a jogtudományok doktora, professzor, a polgári jog és eljárások tanszékének vezetője. E-mail címe: sibilla.buletsa@,uzhnu.edu.ua

${ }^{2}$ Csepisz Oleszja, PhD, az Ungvári Nemzeti Egyetem Állami Felsőoktatási Intézmény jogi karán a jogtudományok kandidátusa, egyetemi docens, a polgári jog és eljárások tanszékének docense. E-mail címe: olesya.chepys@uzhnu.edu.ua

${ }^{3}$ Revucka Irina, PhD, az Ungvári Nemzeti Egyetem Állami Felsőoktatási Intézmény jogi karán a jogtudományok kandidátusa, a polgári jog és eljárások tanszékének docense. E-mail címe: irina.revutska@uzhnu.edu.ua 
Biztosítási megállapodás, mint az önkéntes biztosítási kötelezettségek keletkezésének alapja Ukrajnában

Keywords: insurance, insurer, insurance contract, voluntary and compulsory insurance

\section{BEVEZETÉS}

A világgyakorlat nem teremtett ésszerűbb és hozzáférhetőbb mechanizmust a társadalom érdekeinek védelmére, mint a biztosítás. A biztosítás a gazdaság ösztönzésének, az egyes egyének gazdasági tevékenységének fontos tényezője, mivel magabiztosságot ad a vállalkozói tevékenység fejlesztésében. Egy tulajdonos sem fekteti be tőkéjét az áru vagy szolgáltatás szférájának fejlesztésébe anélkül, hogy ne venné figyelembe az előlegezett források elvesztésének kockázatát. Átadva a felelősséget a kockázat következményeiért a biztosítónak kisebb dij ellenében, a befektető biztos abban, hogy a biztosítási károk megtérülnek.

A biztosítás a polgári jogviszonyok egyike a polgárok és jogi személyek vagyoni érdekeinek védelme érdekében a biztosítási szerződés vagy a hatályos törvény által meghatározott bizonyos események bekövetkezte esetén (biztosítási esetek) a pénzalapokból, amelyek a polgárok és jogi személyek által fizetett biztosítási díjak alapján alakulnak (biztosítás járulékok, biztosítási dijak) és az ezen alapokból származó pénzeszközök elhelyezéséből származó jövedelmekből (Ukrajna „A biztosításról" szóló törvény 1 . cikkelye). ${ }^{4}$ A törvény meghatározza a biztosítási koncepciót alkotó fó elemeket. Ez a célja elsősorban a biztosításnak - az egyének és jogi személyek vagyoni érdekeinek védelme. A mai piaci környezetben a vállalkozásoknak nemcsak a természeti katasztrófákkal kapcsolatos vagy vagyoni károk (földrengés, árvíz, vihar stb.), technikai és technogén jellegú véletlen események (tűzvész, baleset, robbanás stb.) következtében keletkező veszteségek kompenzálására van szükségük, hanem a meg nem kapott nyereségért járó ellentételezés, a többletköltségek a vállalat kényszerû leállása (a nyersanyagok nem időben történő szállítása, a vevők fizetésképtelensége és egyéb előre nem látható körülmények), az adójogszabályok, a számviteli politika változása miatt is stb. Egyre inkább a biztosítás tárgyává válnak a különböző pénzügyi és gazdasági károk (magas infláció, árfolyam ingadozások stb.) és bűnözői

${ }^{4}$ Про господарські товариства: Верховна Рада України; Закон України від 19.09.1991 № 1576-XII. 
jelenségek (lopás, rablási támadások, járműlopás stb.). Így a biztosítás hozzájárul a gazdasági biztonság megszervezésére irányuló erőforrások optimalizálásához.

Formája szerint a biztosítás lehet kötelező és önkéntes. A kötelező biztosítás a kényszerítés elvein alapul, a törvény alapján keletkezik, függetlenül a biztosítási viszonyban résztvevők szándékától, pénzügyi lehetőségeitôl. Ukrajna „A biztosításról” szóló törvényének 7. cikkelyében fel vannak sorolva a kötelező biztosítás típusai, amelyeket Ukrajnában végrehajtanak / vagy végre kell hajtani (például a szárazföldi jármúvek tulajdonosainak felelősségbiztosítása, magasabb kategóriájú sportolók biztosítása stb). Az önkéntes biztosítás olyan biztosítás, amely a biztosított és a biztosító közötti megállapodás alapján történik. Ukrajna „A biztosításról" szóló törvényének 6 . cikkelye szerint az önkéntes biztosítás lehet életbiztosítás, balesetbiztosítás, egészségbiztosítás (folyamatos egészségbiztosítás), egészségbiztosítás betegség esetén, rakomány- és poggyászbiztosítás stb.

\section{A BIZTOSÍTÁSI SZERZŐDÉS FOGALMA, JOGI JELLEMZŐI, A FELEK ÉS AZ ALAPVETŐ FELTÉTELEK}

Az önkéntes biztosítás alapja a polgári jogi szerződés. Kyle R. Knipper, a brémai egyetem professzora szerint a szerződés egyrészt a legfontosabb kiválósági eszköz a vagyonforgalom stabilitásának és fenntartásának, valamint a piacgazdaság dinamikájának megteremtésében és fenntartásában, másfelől a szerződés csak azért bírhat jelentőséggel, mert a tulajdon mellett garantált jogi címet is $a{ }^{5} .^{5}$ A biztosítási szerződés értelmében az egyik fél (a biztosító) egy adott esemény (biztosítási esemény) előfordulása esetén vállalja, hogy kifizeti a másik félnek (a biztosítottnak) vagy a szerződésben meghatározott másik személynek a pénzösszeget (biztosítási díjat), a biztosított pedig vállalja a biztosítási díj kifizetését és teljesíti a szerződés egyéb feltételeit (az ukrán Polgári Törvénykönyv 979. cikkelye). ${ }^{6}$ A biztosítási szerződés jogi jellemzői szerint lehet:

5 Кніпер К.Р. ВАасність, володіння та ї відображення в договірному праві. Право України. 2012. № 9. С. 37- 43.

${ }^{6}$ Цивільний кодекс України: Верховна Рада України; Кодекс України віл 16.01.2003 № 435-IV. 
- kétoldalú, mivel szerződés esetén a vonatkozó jogok és kötelezettségek mind a biztosított, mind a biztosító részére létrejönnek;

- reális, az első biztosítási kifizetés napjától lép hatályba, hacsak a megállapodás másként nem rendelkezik;

- visszatéritéses, mivel a biztosított fizeti a biztosítási dijat, a biztosító biztosítási esemény esetén biztosítási kifizetést;

- aleatory (kockázatos) - kockázati szerződés, vagyis a szerződés megkötésekor a felek nem tudják egyértelműen meghatározni feladataik teljesítésének határait, és az egyik fél vesztesége vagy meggazdagodása az esettől függ.

Ukrajna jogszabályai szerint a biztosítási jogviszonyok szubjektív összetétele sajátságos. A biztosítási szerződésben részt vevő felek - a biztosító és a biztosított. A szerződés résztvevője lehet: biztosított személy, kedvezményezett, biztosítási ügynök és biztosítási bróker. A biztosító olyan személy, aki vállalja a vagyon elvesztésének, a biztosított egészsége károsodásának vagy halálának kockázatát, és bizonyos események bekövetkezésekor köteles meghatározott összeg kifizetésére a biztosított vagy más meghatalmazott személy részére. Ukrajna „A biztosításról” szóló törvénye 2. cikkelye szerint biztosítóként ismerik el: 1) a rezidens biztosítókat - pénzügyi intézmények, amelyek részvénytársaságok formájában lettek létrehozva, teljes és betéti társaságokat vagy kiegészítő felelősségű társaságokat „A gazdasági társaságokról” szóló ukrán törvény értelmében ${ }^{7}$, figyelembe véve, hogy minden ilyen pénzügyi intézmény résztvevőinek legalább háromnak kell lennie, valamint az e törvényben meghatározott egyéb jellemzőket, és az előírt módon kaptak biztosítási tevékenységre vonatkozó engedélyt; 2) a pénzügyi szolgáltatások piacán az állami szabályozást végző Nemzeti Bizottságba nyilvántartásba vett, az ukrán jogszabályokkal összhangban a külföldi biztosítótársaságok fióktelepeinek állandó képviselőit, akik a megállapított eljárás szerint szintén rendelkeznek a biztosítási tevékenységhez szükséges engedéllyel (a külföldi illetőségű biztosítók fióktelepei). A biztosítónak az életbiztosításon kívüli biztosítási formákkal foglalkozó engedélyezett alap (garanciabetét) minimális mértéke 1 millió eurónak felel meg, az életbiztosítással foglalkozó biztosítónak pedig 10 millió euró az ukrán valuta árfolyamán. A biztosítók

7 Про господарські товариства: Верховна Рада України; Закон України від 19.09.1991 № 1576-XII. 
biztosítási tevékenységet végezhetnek biztosítási közvetítőkön keresztül: biztosítási brókerek és biztosítási ügynökök. Biztosított személy, aki bizonyos események bekövetkezése ellen biztosítja önmagát, vagyonát vagy harmadik személyt és annak tulajdonát. A biztosítottak olyan jogi személyek és cselekvőképes állampolgárok, akik biztosítási szerződéseket kötöttek a biztosítókkal vagy ilyenek a jogszabályok szerint.

A biztosítási szerződés lényeges feltételei: a szerződés tárgya; biztosítási eset; az a pénzösszeg, amelyet a biztosító köteles fizetni egy biztosított esemény bekövetkezte esetén (biztosított összeg); a biztosítási díj mértéke és a fizetés határideje; a szerződés időtartama és a polgári jogi okiratokban meghatározott egyéb feltételek.

\section{A BIZTOSÍTÁSI SZERZŐDÉS MEGKÖTÉSE}

A biztosítási szerződést írásban készítik (ukrán Polgári Törvénykönyv 981. cikkelye). Ugyanakkor a biztosítási szerződés írásos formája kétféle módon fejezhető ki: a felek által aláírt egyik dokumentum elkészítésével és a biztosítási igazolás kiadásával a biztosítottnak a biztosító által (biztosítási kötvény, tanúsítvány), amely ténylegesen igazolja a szerződés megkötésének tényét. Az írásos formanyomtatvány be nem tartása esetén a szerződés semmis. Azonban Ukrajna Polgári Törvénykönyvének 983. cikkelye és Ukrajna „A biztosításról” szóló törvénye 18. cikkelye szerint a biztosítási szerződés csak az első biztosítási kifizetés után lép hatályba, kivéve, ha másként rendelkezik a biztosítási szerződés. Ez a sajátosság lehetővé teszi, hogy a biztosítási szerződést valós polgári jogi szerződésekhez sorolják.

A biztosítási szerződés megkötésére irányuló eljárás általános, és magában foglalja az egyik fél ajánlatának végrehajtását és egy ilyen ajánlat elfogadását a másik fél által. A biztosítási szerződés megkötésére a biztosított írásos kérelmet nyújt be a biztosítónak a biztosító által létrehozott formanyomtatványon, vagy másként nyilatkozik a biztosítási szerződés megkötésére irányuló szándékáról. A nyilatkozat minden olyan körülményt jelez, amely elengedhetetlen a biztosítási kockázat meghatározásához. A biztosítónak továbbá joga van a biztosítottól mérleget kérni vagy pénzügyi helyzetének kimutatását, amelyet a könyvvizsgáló (könyvvizsgáló cég) alátámaszt. Miután a szerződő felek megállapodást kötöttek a szerződés minden lényeges feltételéről, valamint a biztosított által fizetett biztosítási díjról, a biztosító elkészíti a biztosítási kötvényt. A biztosítási kötvény a kötvénytulajdonos számára kiállított okmány, ami 
közvetlenül igazolja a szerződés szerinti biztosítási tényt a szerződésnek vagy a hatályos jogszabályoknak megfelelően, megerősíti a kötelező biztosítási feltételeket és tartalmazza a biztosítási kötvénytulajdonosnak a szerződés feltételeiben meghatározott összeg kifizetését a biztosítási esemény megtörténtekor (biztosítási kártalanítás).

Ukrajna „A biztosításról” szóló törvénye 16. cikkelye szerint a biztosítási szerződésnek tartalmaznia kell: a dokumentum címét; a biztosító nevét és címét; családnevét, utónevét, apai utónevét vagy a biztosított nevét és a biztosított személy nevét, címét és születési idejét; a kedvezményezett családnevét, utónevét, apai utónevét, születési idejét és címét; a biztosítás tárgyának feltüntetését; az életbiztosítási szerződéstől eltérő biztosítási szerződés szerinti biztosítási összeget; a biztosított összeg nagyságát és (vagy) az életbiztosítási szerződés szerinti biztosítási összeget; a biztosítási esetek listáját; a biztosítási díjak nagyságát (kifizetések, díjak) és a kifizetések határidejét; biztosítási rátát (a biztosítási díjat nem határozzák meg olyan biztosítási esetekben, amelyeknél a biztosított összeg nincs meghatározva); a szerződés időtartamát; a szerződés módosítására és megszüntetésére vonatkozó eljárást; a biztosítási kifizetések feltételeit; a biztosítási kártalanítás megtagadásának okait; a felek jogait és kötelezettségeit, valamint a szerződési feltételek nem teljesítésének vagy helytelen teljesítésének felelősségét; egyéb feltételeket a felek egyetértésével; a felek aláirását. ${ }^{8}$

A biztosítási szerződés feltételei nemcsak a felek által aláirt egyetlen dokumentumban vagy a biztosítási kötvényben állapíthatók meg, hanem a biztosítási szabályokban is. A biztosítási szabályokat a biztosító minden biztosítási típushoz külön kidolgozza és a Nemzeti Bizottságnál nyilvántartásba vételre kerül, amely szabályozza a pénzügyi szolgáltatások piacát, amikor engedélyt ad ki a megfelelő típusú biztosítás megvalósításának jogához. Ugyanakkor a Nemzeti Pénzügyi Szolgáltatások felhívják a figyelmet a szabályok megfelelésére a törvény követelményeinek, valamint hogy egyes rendelkezések ne vezessenek a kötvénytulajdonosok esetleges visszaéléseihez. Ezenkívül a biztosítási dijak kifizetését nyomon követik. ${ }^{9}$

${ }^{8}$ Про страхування: Верховна Рада України; Закон України від 07.03.1996 № 85/96BP.

9 Медвіль Я. Ф. Особливості державного регулювання і нагляду за страховою діяльністю в Україні Наше право. 2013. № 13. С. 149-152.о. 


\section{A FELEK JOGAINAK ÉS KÖTELEZETTSÉGEINEK SAJÁTOSSÁGAI A BIZTOSÍTÁSI SZERZŐDÉS ALAPJÁN}

A biztosítási szerződésben részt vevő felek jogait és kötelezettségeit a hatályos jogszabályok határozzák meg (az Ukrán Polgári Törvénykönyv 988. és 989. cikkelye, valamint Ukrajna „A biztosításról” szóló törvénye 20. és 21. cikkelye) és a szerződés, amelyet megkötnek. ${ }^{10}$

A biztosító köteles: 1) megismertetni a biztosítottat a biztosítás feltételeivel és szabályaival. A biztosítónak meg kell adnia a szükséges információkat a biztosítás feltételeiről és szabályairól, mivel a biztosítás típusától és tárgyától függően határozzák meg azokat; tájékoztatni a biztosítottat az általa ismert körülményekről, amelyek elengedhetetlenek a biztosított esemény bekövetkezése valószínűségének meghatározásához és a lehetséges veszteségek nagyságához; 2) két munkanapon belül, amint tudomást szerez a biztosított esemény bekövetkeztéről, intézkedéseket hozni a biztosítási díjnak a biztosított számára időben történő kifizetésekhez szükséges valamennyi dokumentum elkészítésére; 3) a biztosítási esemény megtörténte esetén megvalósítani a biztosítási díj kifizetését a szerződésben megállapított határidőn belül. A biztosító vagyonilag felelős a biztosítási díj (biztosítási kártalanítás) időben történő végrehajtásáért bánatpénz (bírság, kamat) megfizetésével, amelynek összegét a biztosítási szerződés feltételei határozzák meg; 4) megtéríteni a biztosított által a biztosítási esemény esetén felmerült költségeket a kár megelőzése vagy csökkentése érdekében, amennyiben azt a szerződés megállapítja; 5) a biztosítás igénybevétele esetén, amennyiben a biztosító a biztosítási kockázat csökkentését célzó intézkedésekkel vagy a vagyon értékének növelésével jár, megfelelő változtatásokat tenni a biztosítási szerződésben; 6) nem terjeszteni az információkat a biztosítottról és a vagyonjogi helyzetéről, kivéve a törvény által meghatározott eseteket.

A biztosított köteles: 1) a biztosítási kifizetéseket kellő időben (járulékok, bónuszok) a szerződésben meghatározott összegben megtenni; 2) a biztosítási szerződés megkötésekor tájékoztatni a biztosítót a biztosítási kockázat értékeléséhez elengedhetetlenül szükséges valamennyi körülményrôl, és a továbbiakban tájékoztatni azt a biztosítási kockázat bármilyen változásáról; 3) a biztosítási szerződés megkötésekor értesíteni a

10 Про страхування: Верховна Рада України; Закон України віА 07.03.1996 № 85/96BP. 
biztosítót a biztosítás tárgyát képező egyéb biztosítási szerződésekről; 4) intézkedni a biztosítási esemény bekövetkezte által okozott veszteségek megelőzésére; 5) tájékoztatni a biztosítót a biztosított esemény bekövetkezéséről a szerződésben meghatározott időtartamon belül. A törvény által előírt kötelezettségek listája nem kimerítő jellegű, ezért a felek megállapodás alapján másokat is létrehozhatnak.

E kötelezettség megfelelő teljesítésének elősegítése érdekében a biztosítónak jogában áll megtagadni a biztosítási kifizetést (ukrán Polgári Törvénykönyv 991. cikke, Ukrajna „A biztosításról” szóló törvénye 26. cikkelye): 1) a biztosított vagy annak a személynek szándékos intézkedése, akinek a javára a biztosítási szerződést kötötték, ha az a biztosított esemény bekövetkeztére irányultak, kivéve azokat a polgári vagy hivatalos cselekményeket, amelyek a polgári vagy szolgálati kötelezettségek teljesítésével kapcsolatosak a szükséges védelem véghezvitelekor (annak határai túllépése nélkül), vagy a vagyon, az élet, az egészség, a becsület, a méltóság és az üzleti hírnév védelme érdekében; 2) a biztosított vagy a biztosítási szerződés megkötésére jogosult személy által a biztosítási eseményhez vezetô szándékos bűncselekmény elkövetése; 3) a biztosított által tudatosan hamis információ benyújtása a biztosítás tárgyáról vagy a biztosított esemény bekövetkezésének tényéről; 4) a vagyoni biztosítási szerződés alapján teljes kártérítés kézhezvétele az elkövetőtől a biztosított által; 5) a biztosított által nem megfelelő időben történt értesítés alapos ok nélkül a biztosítási esemény bekövetkeztéről vagy a biztosító akadályozása a kár körülményeinek, jellegének és összegének meghatározása során; 6) a törvény által megállapított egyéb okok fennállása.

\section{A BIZTOSÍTÁSI SZERZŐDÉS MEGSZŰNÉSÉNEK OKAI ÉS JOGI KÖVETKEZMÉNYEI}

Ukrajna „A biztosításról” szóló törvénye 28. cikkelye alapján a biztosítási szerződés érvényessége megszűnik a felek egyetértésével, valamint abban az esetben, ha:_1) e megállapodás lejárt; 2) a biztosító kötelezettségeinek teljes körű teljesítése a biztosított részére; 3) a biztosított által nem fizetett biztosítási díj esetén a szerződésben meghatározott időben; 4) a biztosító jogi személyének felszámolása vagy a biztosított állampolgár elhalálozása vagy cselekvőképessége elvesztése esetén, kivéve a törvény által előírt eseteket; 5) a biztosító felszámolása az ukrán jogszabályok által megállapított eljárásnak megfelelően; 6) a biztosítási 
szerződés érvénytelenségének elismeréséről szóló bírósági határozat elfogadása esetén; 7) egyéb, Ukrajna jogszabályai által előírt esetekben. ${ }^{11}$

Ukrajna Polgári Törvénykönyve 997. cikkelye szerint mind a biztosító, mind a biztosított eltekinthet a biztosítási szerződéstől. Így ha a biztosított a biztosítási díj megfizetését késleltette, és a biztosítónak a biztosítási díj kifizetésére vonatkozó írásbeli kérelme benyújtásától számított tíz munkanapon belül nem fizette meg azt, akkor a biztosító a szerződés eltérő rendelkezése hiányában megszüntetheti a biztosítási szerződést.

A biztosító vagy a biztosított köteles a másik felet értesíteni a szerződés megszüntetésének szándékáról a szerződés megszűnésétől számított harminc napon belül, kivéve, ha a szerződés másként rendelkezik. Ebben az esetben a biztosítónak nincs joga ahhoz, hogy a biztosított hozzájárulása nélkül visszavonja a biztosítási szerződést, aki nem engedélyezi a szerződés megsértését, hacsak a szerződés vagy a törvény másként nem rendelkezik.

Ha a biztosítási kötvénytulajdonos a biztosítási szerződéstôl eltekint (az életbiztosítási szerződésen kívül), akkor a biztosító a szerződés lejárta előtt visszafizeti a biztosítási kifizetéseket arra az időre, amennyi maradt a szerződés érvényességének a lejártáig, kivéve a biztosítási díj kiszámításakor meghatározott ügyleti költségeket, valamint a biztosító tényleges biztosítási díjait. Ha a szerződő fél a szerződés elutasítását a szerződés feltételeinek a biztosító általi megsértése okozza, a biztosító visszaküldi a biztosítottnak az általa teljes egészében kifizetett biztosítási díjakat. Ha a biztosító lemondott a biztosítási szerződésről (kivéve az életbiztosítási szerződést), akkor visszaküldi a biztosítottnak az általa teljes egészében kifizetett biztosítási díjat. Ha a biztosító elutasítja a szerződést a biztosítási szerződés feltételeinek a szerződő fél általi elmulasztásának következtében, a biztosító a szerződés lejárta előtti hátralévő időszakra visszatéríti a biztosított biztosítási kifizetéseit, eltekintve a biztosítási díj kiszámításakor meghatározott esetleges szokásos kiadásoktól, és a ténylegesen kifizetett biztosítási díjat.

Ukrajna Polgári Törvénykönyve (998. cikkely) és Ukrajna „A biztosításról" szóló törvénye 29. cikkelye előírja a különleges esetek érvénytelenítését is a biztosítási szerződésben. A bíróság a biztosítási szerződést érvénytelennek nyilvánítja, ha: 1) a biztosítási esemény

11 Про страхування: Верховна Рада України; Закон України від 07.03.1996 № 85/96BP. 
bekövetkeztét követően kötötték meg; 2) a biztosítási szerződés tárgya olyan vagyontárgy, amely bírósági ítélet vagy hatályba lépett ítélet alapján lefoglalásra kerül ${ }^{12}$; 3) Ukrajna Polgári Törvénykönyve 215-236. cikkelyeiben előírtak alapján a cselekményekre vonatkozó indokok érvénytelennek való elismerése (a polgári jogi cselekményekkel, valamint a társadalom erkölcsi elveivel való ellentmondás, a cselekmény fiktív és színlelt, a megegyezés megkötése hibás volt, megtévesztés stb.).

\section{A BIZTOSÍTÁSI SZERZŐDÉSEK MEGKÖTÉSÉNEK DINAMIKÁJA UKRAJNÁBAN}

2019 első félévében Ukrajnában a megkötött biztosítási szerződések száma 1325,8 ezerrel (vagyis 2,8\%-kal) csökkent, 400.1 ezerrel (vagy 2,4\%) csökkent az önkéntes biztosítási szerződések száma, ideértve a megkötött balesetbiztosítási szerződések számának csökkentését 461,2 ezerrel (vagy 5\%), a megkötött pénzügyi kockázati biztosítási szerződések száma 206,2 ezerrel (vagy 36,1\%) csökkent. A kötelező biztosítási szerződések száma 1388,6 ezerrel (vagyis 4,6\%-kal) csökkent, mivel a közlekedési balesetekre kötött biztosítási szerződések száma 1581,3 ezerrel (5,5\%) csökkent. ${ }^{13}$

2019 első félévében 501104 személynek volt biztosítása, ami 36,6\%kal vagy 289248 fővel kevesebb, mint 2018 ugyanezen időszakában (2016 első felében 790352 személy volt biztosítva).

2019 első felében a magánszemélyekkel kötött szerződések számában a következő változások mentek végbe:

- a közlekedési balesetekre megkötött biztosítási szerződések száma 14151,5 ezerrel (47675,2 ezerre) nőtt 2018 első félévének végéig a megfelelő mutatókhoz képest;

- a megkötött balesetbiztosítási szerződések száma 12818,7 ezerrel (15795,9 ezerre) nőtt 2018 első félévének megfelelő mutatóihoz képest;

- a megkötött pénzügyi kockázati biztosítási szerződések száma 3016,4 ezerrel (4339,6 ezerig) nőtt 2018 első félévének megfelelő mutatóihoz képest;

12 Про страхування: Верховна Рада України; Закон України віА 07.03.1996 № 85/96BP.

13 Підсумки діяльності страхових компаній за I квартац 2019 року 
- a betegség esetére megkötött egészségbiztosítási szerződések száma 2457,0 ezerrel (2952,4 ezerre) nőtt a megfelelő mutatókhoz képest 2018 első félévének végére;

- a megkötött vagyonbiztosítási szerződések száma 150,6 ezerrel (1568,1 ezerre) nőtt a megfelelő mutatókhoz képest 2018 első félévének végére;

- a tûzveszélyre és a természeti katasztrófák kockázatára vonatkozó megkötött szerződések száma 180,8 ezerrel (879,5 ezerig) csökkent a megfelelő mutatókhoz képest 2018 első félévének végén;

- a megkötött életbiztosítási szerződések száma 305,5 ezerrel csökkent (201,2 ezerig), szemben a megfelelő mutatókkal 2018 első félévének végén.

\section{KONKLÚZIÓ}

Az egyik biztosítási forma Ukrajnában az önkéntes biztosítás, amelynek alapja a szerződés. A biztosítási szerződés jogi cselekmény, amely szerint az egyik fél (a biztosító) egy adott esemény (biztosítási esemény) bekövetkezése esetén vállalja, hogy a másik félnek (a biztosított) vagy a szerződésben meghatározott másik személynek kifizeti a pénzösszeget (biztosítási kifizetés), és a biztosított vállalja, hogy biztosítási díjat fizet és teljesíti a szerződés egyéb feltételeit (ukrán Polgári Törvénykönyv 979. cikkelye). ${ }^{14} \mathrm{~A}$ jogi jellemzők szerint a biztosítási szerződés: kétoldalú, reális, visszatérítéses, aleatory (kockázatos).

A biztosítási szerződés jellemzői Ukrajnában:

1) az adott szerződés aleatory, azaz kockázatos (a felek a szerződés megkötésekor nem tudják egyértelmúen meghatározni feladatkörük határait);

2) az alapvető feltételek közé tartozik: a szerződés tárgya; a biztosítási eset; az a pénzösszeg, amelyet a biztosító köteles fizetni egy biztosított esemény bekövetkezése esetén (biztosított összeg); a biztosítási dij mértéke és a fizetés határideje; a szerződés időtartama és a polgári jogi okmányokban meghatározott egyéb feltételek. Sajátossága abban rejlik, hogy a biztosítási szerződés feltételei nemcsak a felek által aláírt egyetlen dokumentumban

14 Цивільний кодекс України: Верховна Рада України; Кодекс України віА 16.01.2003 № 435-IV. 
vagy a biztosítási kötvényben vannak megállapítva, hanem a biztosítási szabályokban (helyi okmányok) is;

3) a biztosítási szerződés hatályba lépésének időpontja egyedi. Jóllehet a törvény egyszerú írásos formát ír elô, azonban a felek mindennemű feltételek mellett még írásban is megegyeznek, mert nem elegendő egy ilyen szerződés hatálybalépéséhez. A biztosítási szerződések sajátossága Ukrajnában az, hogy csak abban az esetben lépnek hatályba, ha a biztosított az első biztosítási kifizetést teljesíti, hacsak a szerződés másként nem rendelkezik. Ezért reálisak ezek a szerződések, nem pedig konszenzusosak;

4) a biztosítók és biztosítottak jogainak és törvényes érdekeinek védelme érdekében a felek e megállapodás szerinti alapvetô jogait, kötelezettségeit és felelősségét egyértelműen meghatározza a jogszabály;

5) Ukrajnában az év első felében az önkéntes biztosítási szerződések számának növekedése figyelhető meg (különösen a balesetekre és a pénzügyi kockázatokra kötött biztosítás) és a kötelező biztosítási szerződések csökkenése.

\section{FELHASZNÁLT IRODALOM}

ПіАсумки Аіяльності страхових компаній за I квартал 2019 року Elérhető: https://forinsurer.com/ files/file00658.pdf (Letöltve: 2020. 03. 28.)

Кніпер К.Р. ВАасність, володіння та ї відображення в Аоговірному праві. Право України. 2012. № 9. С. 37- 43.

Медвіль Я. Ф. Особливості державного регулювання і наглялу за страховою Аіяльністю в Україні Наше право. 2013. № 13. С. 149_ 152.

Про господарські товариства: Верховна Рада України; Закон України віА 19.09.1991 № 1576-XII. Elérhető:

http://zakon3.rada.gov.ua/laws/show/1576-12 (Letöltve: 2020. 03. 28.)

Про страхування: Верховна Рада України; Закон України віА 07.03.1996

№ 85/96-BP. Elérhető: http://zakon3.rada.gov.ua/laws/show/85/96вp (Letöltve: 2020. 03. 28)

Цивільний кодекс України: Верховна РаАа України; Кодекс України віА 16.01.2003 № 435-IV. Elérhető:

http://zakon2.rada.gov.ua/laws/show/435-15 (Letöltve: 2020. 03. 28.) 